\title{
The Human Homolog of Murine Evi-2 Lies Between Two von Recklinghausen Neurofibromatosis Translocations
}

\author{
Peter O’Connell, * David Viskochil, * Arthur M. Buchberg, $†$ Jane Fountain, $\ddagger$ \\ Richard M. Cawthon, * Melanie Culver, * Jeffrey Stevens, * Donna C. Rich,\$ \\ David H. Ledbetter, $\S$ Margaret Wallace, $\ddagger$ John C. Carey, Nancy A. Jenkins, $†$ \\ Neal G. Copeland, † Francis $S$. Collins, $†$ and Ray White* \\ ${ }^{*}$ Howard Hughes Medical Institute, University of Utah, Salt Lake City, Utah 84132; †BRI-Basic Research Program, NCI-Frederick \\ Cancer Research Facility, Frederick, Maryland 21701; $¥$ Howard Hughes Medical Institute and University of Michigan, \\ Ann Arbor, Michigan 48109; §Institute for Molecular Genetics, Baylor College of Medicine, Houston, Texas 77030; \\ and "Department of Pediatrics, University of Utah, Salt Lake City, Utah 84132
}

Received January 31, 1990; revised March 21, 1990

\begin{abstract}
Von Recklinghausen neuroflbromatosis (NF1) is one of the most common inherited human disorders. The genetic locus that harbors the mutation(s) responsible for NF1 is near the centromere of chromosome 17, within band q11.2. Translocation breakpoints that have been found in this region in two patients with NF1 provide physical landmarks and suggest an approach to identifying the NF1 gene. As part of our exploration of this region, we have mapped the human homolog of a murine gene (Evi-2) implicated in myeloid tumors to a location between the two translocation breakpoints on chromosome 17. Cosmid-walk clones define a 60 -kb region between the two NFI translocation breakpoints. The probable role of Evi2 in murine neoplastic disease and the map location of the human homolog suggest a potential role for $E V I 2$ in NF1, but no physical rearrangements of this gene locus are apparent in 87 NF1 patients. @1990 Academic Press, Inc.
\end{abstract}

\section{INTRODUCTION}

Neurofibromatosis type 1 (NF1), also known as von Recklinghausen disease, is an autosomal dominant disorder that occurs at a frequency of 1 in 4000 (Crowe et al., 1956; Stumpf et al., 1988). NF1 is a clinical diagnosis defined by criteria developed through a consensus conference at the National Institutes of Health (Stumpf et al., 1988). The most common physical signs of this condition are multiple subcutaneous nodules (neurotibromas) and pigmented patches of skin (cafeau-lait spots). Patients with NF1 are at significantly increased risk for development of malignancies (e.g., see Riccardi and Eichner, 1986). The NF1 locus has been mapped, by means of genetic linkage studies, to the vicinity of the centromere of human chromosome 17 (Barker et al., 1987; Seizinger et al., 1987; Goldgar et al., 1989); recently its location has been narrowed to band 17q11.2 (Schmidt et al., 1987; Ledbetter et al., 1989).

A strategy for cloning and characterizing the NF1 gene took form when two independent translocations, both with breakpoints located within band 17q11.2, were found in NF1 patients. Because the translocations are the likely cause of neurofibromatosis in these patients, presumably through alteration of the structure or expression of the normal gene at the NF1 locus, the translocation breakpoints provide two operational definitions of genomic clones near the locus. Provided that the two breakpoints do not occur at exactly the same place, some components of the gene would likely map between them.

To test this hypothesis, a large number of cosmid DNA probes were isolated from two somatic cell hybrid lines that each contain only a small segment of human chromosome 17. These cosmid clones have been mapped to the NF1 region by genetic linkage and by physical methods (Fountain et al., 1989a; O'Connell et al., 1989a). We recently reported that two of these probes identified a large DNA fragment that differed in size between normal and translocation chromosomes (Fountain et al., 1989b; O'Connell et al., 1989b).

In addition to the DNA probes developed from somatic cell hybrids, we examined cloned DNAs having oncogenic potential and known to map to this region. In particular, the oncogenes $E R B A 1$ and $E R B B 2$ were examined because they had been localized to the relevant region of chromosome 17. Mapping studies, however, excluded both $E R B$ genes from the vicinity of the NF1 locus (unpublished data). 
In contrast, mapping studies were unable to exclude a putative protooncogene recently identified in murine myeloid tumors (Buchberg et al., submitted for publication) as a candidate for the NF1 gene. Because the mouse gene mapped to a region of murine chromosome 11 that shows extensive homology to human chromosome 17 (Buchberg et al., 1988, 1989), its human counterpart was potentially located near the NF1 locus. Genetic linkage studies in a large panel of reference families revealed that the human homolog, EVI2, does reside on human chromosome 17 , very near other genetic marker loci that are closely linked to the NF1 locus. More precise mapping with somatic cell hybrids containing the segregated translocation chromosomes placed EVI2 between the two NF1 translocation breakpoints and made it a strong candidate for the NF1 gene.

\section{MATERIALS AND METHODS}

\section{Cell Lines}

Epstein-Barr virus-transformed lymphoblastoid cell lines from normal and NF1 individuals were suspension-cultured in RPMI 1640 medium (Cellgro/Mediatech), with $1 \%$ Nutridoma (Boehringer-Mannheim), $5 \%$ bovine calf serum (Hyclone), and 50 units $/ \mathrm{ml}$ gentamicin sulfate. NF1 individuals were defined by the criteria of Stumpf et al. (1988) and were collected under the auspices of the National Neurofibromatosis Foundation or diagnosed by one of us (J.C.C.). The somatic cell hybrids used in this study (identified in Fig. 1) were cultured in D-MEM (Cellgro/Mediatech) containing $10 \%$ fetal bovine serum (Hyclone), supplemented with hypoxanthine, aminopterin, and thymidine (HAT, Boehringer-Mannhiem) to selectively retain chromosome 17; however, hybrid $123 \mathrm{~B}$ was cultured without HAT.

\section{Southern Analysis}

Human DNA samples derived from a panel of 59 reference families (White et al., 1985; Dausset, 1986) were digested using 96-well trays and a Biomek1000 laboratory workstation (Beckman). For somatic cell hybrids, $5 \mu \mathrm{g}$ of control and $10 \mu \mathrm{g}$ of hybrid DNA were digested. Restriction enzyme digests were carried out according to instructions supplied by the manufacturer (Molecular Biology Resources), except that enzymes were used in twofold excess $(5 \times$ for $M s p I)$. Restriction enzyme-digested samples were fractionated on $0.8 \%$ agarose gels in TEAC buffer as previously described (Barker et al., 1984; Cavenee et al., 1984). Transfers were to Gelman Biotrace RP filters in 0.4 $N$ NaOH (Reed and Mann, 1985). Radiolabeling of DNA probes was performed according to Feinberg and Vogelstein (1984). DNA plugs for PFGE were prepared in low- melting-point agarose (Schwartz and Cantor, 1984) and run on a variety of boxes including FIGE (Carle and Olsen, 1984), TAFE (Gardiner et al., 1986), and CHEF (Chu et al., 1986). Electrophoresis took place in 1.0 $1.5 \%$ agarose gels in $0.5 \times$ TBE buffer; DNA gels were depurinated by two 5 -min washes in $0.25 \mathrm{M} \mathrm{HCl}$, immediately before transfer.

Hybridizations took place in $50 \%$ formamide, $5 \times$ SSC, $50 \mathrm{mM} \mathrm{NaPO}_{4}$ (pH 6.5), $2 \times$ Denhardt's solution, and $200 \mu \mathrm{g} / \mathrm{ml}$ sheared, denatured human DNA at $42^{\circ} \mathrm{C}$. Human DNA was included to suppress hybridization to repetitive sequences by radiolabeled cosmids or their subclones. Washes were in $0.1 \times \mathrm{SSC}, 0.1 \%$ SDS at $55-65^{\circ} \mathrm{C}$.

\section{Genetic Linkage Analysis}

Genotypic data were entered into a computer database, and the output listings were checked against the autoradiograms to avoid clerical errors. In addition, all data for recombination of closely linked markers were re-inspected to determine whether misidentification of parents or grandparents was inflating recombination estimates.

Linkage analysis was performed with the LINKAGE program, which provides an iterative method for determining a probable gene order and likely alternatives (Lathrop et al., 1985).

\section{Genomic Libraries}

Genomic libraries were prepared from Sau3A partial digests of genomic DNA, fractionated on $10-40 \%$ sucrose gradients (Seed et al., 1982), and cloned into bacteriophage or cosmid vectors. Phage lifts were carried out with 0.45- $\mu \mathrm{m}$ Biotrans filters (Pall Biodyne) by the method of Benton and Davis (1977). Cosmid colonies were lifted onto 1.2- $\mu \mathrm{m}$ Biotrans filters (Pall Biodyne) by the method of Grunstien and Hogness (1975).

\section{RESULTS}

Hybridization of a human genomic library with an evolutionarily well-conserved, unique-sequence murine genomic probe for the Evi-2 locus, pXS1.9, identified a human genomic DNA clone, phage HU39. A subclone of phage HU39, pHU39.3, revealed a two-allele EcoRI restriction fragment length polymorphism (RFLP) with a major allele of $9.5 \mathrm{~kb}$ and a minor allele of 7.3 $\mathrm{kb}$ (Buchberg et al., unpublished data). Following the conventions for human nomenclature, we now refer to the human locus as $E V I 2$. This marker had an observed heterozygosity of 0.45 in 100 unrelated individuals typed. Linkage analysis gave a maximum lod score of 16.1 at zero recombination between the locus identified by pHU39.3 and the locus defined by c11-2C11, a cos- 
mid previously shown to be tightly linked to NF1 (O'Connell et al., 1989a).

Somatic cell hybrid lines containing NF1 translocation chromosomes provide an independent means of precisely mapping genes that may be close to NF1. The cell line NF13 contains the derivative chromosome 22 [der(22)] from an NF1 patient with a balanced translocation, $\mathrm{t}(17 ; 22)(\mathrm{q} 11.2 ; \mathrm{q} 11.2)$ (Ledbetter et al., 1989). Cell line DCR1 contains the derivative chromosome 1 [der(1)] from an NF1 patient with a different balanced translocation, $\mathrm{t}(1 ; 17)$ (p34.3;q11.2) (Menon et al., 1989). The chromosome 17 content of these hybrid cell lines is illustrated in Fig. 1a.

Because both NF1 translocation hybrid cell lines retain the long arm of chromosome 17 , a gene mapping between the breakpoints would be expected to show no hybridization to DNA from the hybrid containing the more distal of the two translocation breakpoints, but would hybridize to DNA from the hybrid cell containing the translocation breakpoint nearer the centromere. Figure $1 \mathrm{~b}$ shows the hybridization results for one such probe, E-9, an EVI2 cDNA clone (Cawthon et al., 1990). The absence of the human band in lane 4 shows that E-9 sequences are missing from the $t(17 ; 22)$ breakpoint chromosome (NF13). The presence of the human band in lane 5 indicates that E-9 se- quences are present in the $t(1 ; 17)$ breakpoint chromosome (DCR1); this single-copy human locus therefore maps to a region between the NF1 translocation breakpoints. This result also locates the $t(17 ; 22)$ breakpoint distal to the $t(1 ; 17)$ breakpoint (see Fig. 1a).

The nature of the rearrangements, however, might be complex; the EVI2 sequences could be missing from NF13 due to an interstitial deletion, for example. Therefore, further support for the localization of EVI2 sequences between the translocation breakpoints was sought from analysis of DNA in lymphoblastoid cell lines (LCL), derived from normal individuals and from the two NF1 patients with translocations, by pulsedfield gel electrophoresis (PFGE). We previously described two loci, defined by probes p17L1A and c11$1 F 10$, that map respectively to the proximal and distal ends of a $600-\mathrm{kb} ~ N r u I$ fragment. This $N r u I$ fragment is rearranged in both NF1 translocation hybrids (Fountain et al., 1989b; O'Connell et al., 1989b).

Table 1 indicates the fragment mobilities observed following digestion with several enzymes. Probes for the 17L1A and EVI2 loci identify NruI, NotI, BssHII, and SacII fragments of identical mobility. A probe for 11-1F10 identifies an NruI fragment identical in size to those seen with 17L1A (O'Connell et al., 1989b) and

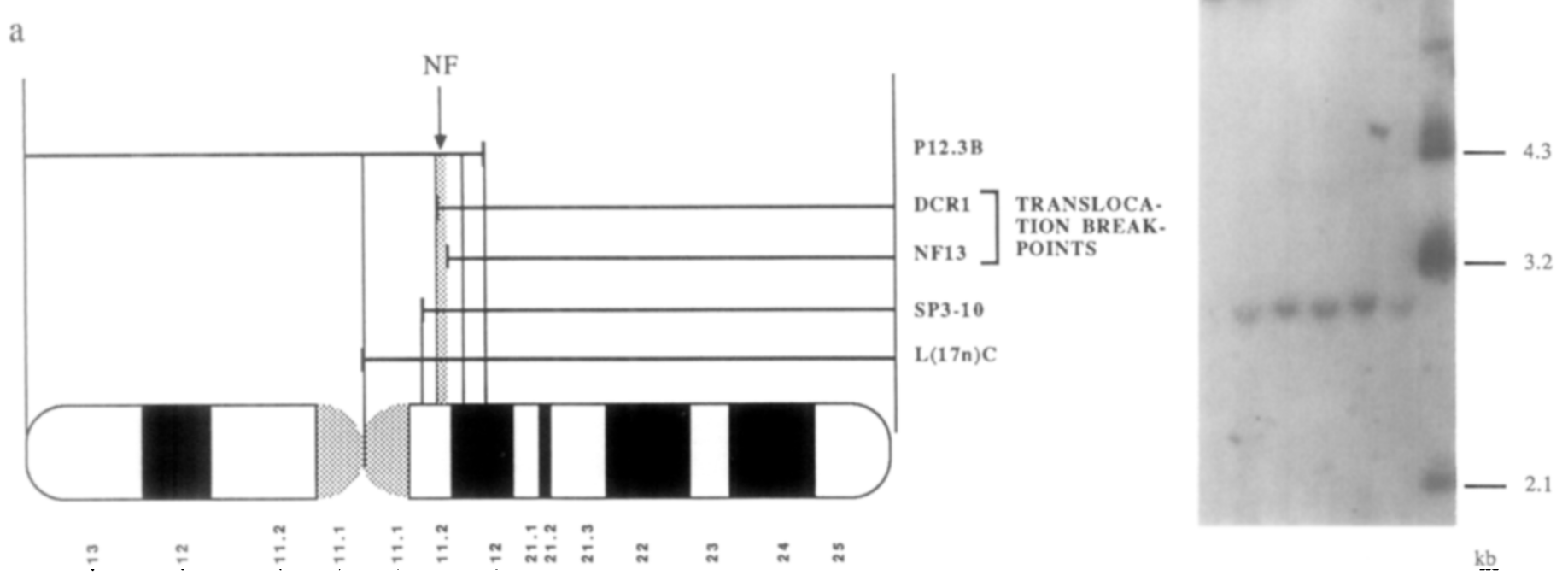

FIG. 1. (a) Mapping panel of somatic cell hybrids for the NF1 region of chromosome 17q. The portions of chromosome 17 present in each hybrid are shown above the diagram; the NF1 region between the translocation breakpoints is shaded (not shown to scale). (b) Hybridization of radiolaheled E-9 (EVI2) to Southern blots of BglII-digested human and somatic cell hybrid DNAs. Lanes (1) human; (2) L(17n)C; (3) SP3-10; (4) NF13; (5) DCR1; (6) P12.3B.; (M) marker. The 10-kb band is human-specific; the rodent-specific 3-kb band represents crosshybridization of EVI2 to its murine homolog. 
TABLE 1

Size (in Kilobases) of PFGE Fragments Detected by EVI2- and NF1-Linked Probes

\begin{tabular}{|c|c|c|c|c|c|c|c|c|c|}
\hline & \multicolumn{9}{|c|}{ Enzyme(s) } \\
\hline & BsshII & ClaI & NotI & NruI & SacII & $\begin{array}{l}\text { BsshIII } \\
+ \text { NotI }\end{array}$ & $\begin{array}{c}\text { ClaI } \\
+ \text { NotI }\end{array}$ & $\begin{array}{c}N r u \mathrm{I} \\
+\quad N o t \mathrm{I}\end{array}$ & $\begin{array}{c}\text { SacII } \\
+ \text { NotI }\end{array}$ \\
\hline \multicolumn{10}{|c|}{ p17L1A } \\
\hline $1^{\circ}$ & $290^{b}$ & 240 & $290^{b}$ & $600^{a}$ & $290^{b}$ & $290^{b}$ & 240 & $290^{b}$ & $290^{b}$ \\
\hline $2^{\circ}$ & $420^{b}$ & 320 & $460^{b}$ & $1000^{a}$ & - & - & 290 & $460^{b}$ & - \\
\hline \multicolumn{10}{|c|}{ pHU39.3 (EVI2) } \\
\hline $1^{\circ}$ & $290^{b}$ & 270 & $290^{b}$ & $600^{\alpha}$ & $290^{b}$ & ND & ND & ND & ND \\
\hline $2^{\circ}$ & $420^{b}$ & 320 & $460^{b}$ & $1000^{a}$ & $470^{a}$ & & & & \\
\hline \multicolumn{10}{|c|}{ c11-1F10 } \\
\hline $1^{\circ}$ & 90 & 190 & 100 & $600^{a}$ & 90 & 90 & ND & ND & ND \\
\hline $2^{\circ}$ & $450^{c}$ & 350 & 220 & $1000^{a}$ & - & 450 & & & \\
\hline
\end{tabular}

Note. $1^{\circ}$, limit digest; $2^{\circ}$, first partial digest; - , no bands visible; ND, not done.

${ }^{a}$ Cross-hybridized with all probes.

${ }^{b}$ Cross-hybridized with p17L1A and EVI2 probes.

' Cross-hybridized with EVI2 probes and c11-1F10.

EVI2 probes, but resides upon different NotI, BssHII, and SacII fragments. Figure 2a shows the PFGE-derived map of the region, deduced from the data shown in Table 1. The approximate positions of the NF1 translocations are shown. Several HTF islands (Bird, 1986) are indicated by the clusters of restriction sites for enzymes with $\mathrm{CpG}$ dimers in their recognition sites.

The order centromere-17L1A-t $(1 ; 17)-E V I 2-$ $\mathrm{t}(17 ; 22)-11-1 \mathrm{~F} 10$-telomere is indicated by the mapping of $E V I 2$ between the translocation breakpoints, with 17L1A proximal and $11-1 \mathrm{~F} 10$ distal to both breakpoints. PFGE analysis of fragments from the translocation chromosomes has provided further support for this order. Since all of these probes are mapped to the same $\mathrm{NruI}$ fragment in normal lymphoblasts (Fig. 2b), the order shown above predicts that specific derivative $\mathrm{NruI}$ fragments, associated with each of the translocation chromosomes, should also be identified by probes for the EVI2 locus. Specifically, EVI2 and c11-1F10 should map to the same derivative $N r u I$ fragment of the $t(1 ; 17)$ translocation chromosome. Figure $2 \mathrm{c}$ shows that both EVI2 and c11-1F10 are found on the same 450 -kb derivative $\mathrm{NruI}$ fragment of the $\mathrm{t}(1 ; 17)$ translocation chromosome, whereas p17L1A is found on a derivative fragment with an apparent mobility identical to that of the normal NruI fragment. Similarly, p17L1A and $E V I 2$ are found on the same 480 -kb derivative $\mathrm{NruI}$ fragment of the $t(17 ; 22)$ translocation chromosome, whereas c11-1F10 is found on a derivative of $390 \mathrm{~kb}$ (Fig. 2d).
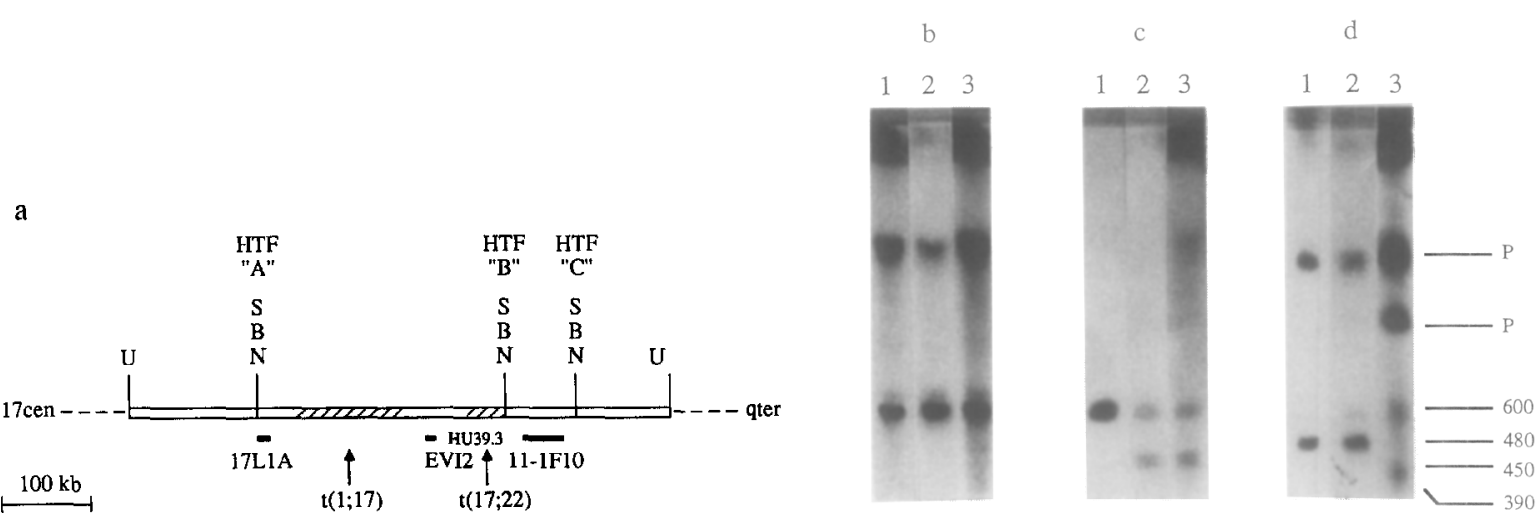

FIG. 2. (a) PFGE map for the 600-kb NruI fragment that encompasses the NF1 translocation breakpoints. Cleavage sites: B, BssHII; N, NotI; S, SacII; U, NruI. Cross-hatching indicates where the translocation breakpoints are localized. The HTF "B" island may contain more than one set of CpG enzyme sites. (b, c, and d) PFGE blots of identical lanes of DNA from (b) Normal LCL, (c) balanced $t(1 ; 17) \mathrm{LCL}$, and (d) balanced t(17;22) LCL, digested with NruI and successively tested with radiolabeled (1) p17L1A; (2) pHU39.3 (EVI-2); or (3) c11-1F10. (P) denotes products of partial digestion. 
To better localize the NF1 translocation breakpoints and provide probes for identifying transcribed regions, cosmid-walking experiments were undertaken. Radiolabeled pHU39.3 identified two contiguous human cosmid clones, designated cEVI20 and cEVI36, from a human genomic library cloned in a derivative of pWE15. A second walk with a radiolabeled 2.1-kb EcoRI subclone (pT320) from the end of cEVI20 identified two additional overlapping cosmids, designated cT311 and cT315. Restriction mapping experiments with these clones resulted in the cosmid contig map shown in Fig. $3 \mathrm{a}$, spanning approximately $80 \mathrm{~kb}$ of genomic DNA.

A series of probes spanning the cosmid contig were tested against DNA blots of the BamHI-, BglII-, and
EcoRI-digested DNA from the NF1 translocation somatic cell hybrid panel in Fig. 1a. As previously shown in Fig. 1b, probe E-9, which is homologous to the $9-\mathrm{kb}$ EcoRI fragment shown in Fig. $3 \mathrm{a}$ and reflects sequences found in both cEVI20 and cEVI36, maps between the translocation breakpoints because it is absent in hybrid NF13 and present in hybrid DCR1. Probe GE1.0 is a 1-kb BglII-EcoRI restriction fragment from cEVI36. As shown in Fig. 3b, it detects an $11.5-\mathrm{kb}$ genomic $E c o R I$ fragment that maps to chromosome $17 \mathrm{q}$, but is absent in both translocation hybrids. Therefore, this fragment of cEVI36 must map proximal to both translocation breakpoints, which means that cEVI36 spans the $t(1 ; 17)$ breakpoint. Since probe BB2.1, a 2.1-kb ge-

a
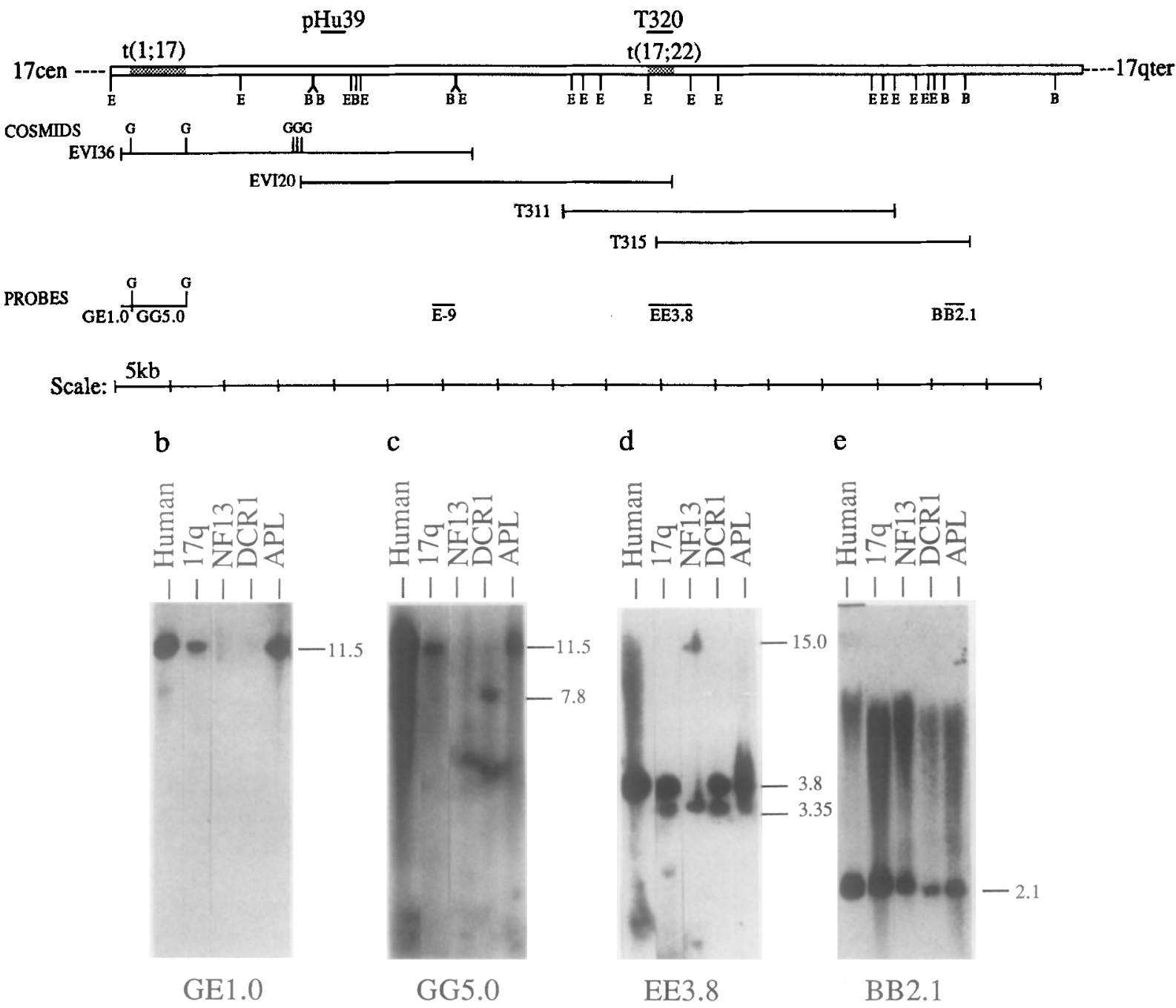

FIG 3. (a) Cosmid contig and restriction enzyme map of the NF1 region. E, EcoRI; B, BamHI; G, BglII. Probes used to ascertain cosmid clones are shown above; probes used to test somatic cell hybrid panels are shown below. (b, c, and d) Autoradiograms of EcoRI digests of a somatic cell hybrid penel, probed with GE1.0, GG5.0, and EE3.8. (e) Autoradiogram of a BamHI digest probed with BB2.1. 
nomic Bam $\mathrm{H} 1$ fragment contained within cT315, maps to chromosome $17 \mathrm{q}$ and also is present in both translocation hybrids (Fig. 3e), it is telomeric of both breakpoints. The contig, therefore, must span both NF1 translocations and is oriented with cEVI36 closest to the centromere. The $t(1 ; 17)$ breakpoint is localized within the contig by probe GG5.0, a 5-kb BglII fragment from cEVI36, which is adjacent to probe GE1.0 and detects the same 11.5-kb genomic EcoRI fragment (Fig. 3c). Unlike probe GE1.0, probe GG5.0 is present in hybrid DCR1, but on a 7.8-kb derivative EcoRI fragment that resulted from the translocation event, and absent from NF13.

The $t(17 ; 22)$ breakpoint is localized by probe EE3.8, a $3.8-\mathrm{kb}$ EcoRI fragment from cT311. In hybrid NF13, a 15-kb derivative fragment is present instead of the normal 3.8-kb EcoRI fragment (Fig. 3d). An identical result was obtained when this experiment was repeated with the most distal $2.3-\mathrm{kb} E c o$ RI fragment from cEVI20 (not shown), indicating that the position of the $t(17 ; 22)$ breakpoint lies within cEVI20. The two NF1 translocation breakpoints thus define a candidate region for NF1 of some $60 \mathrm{~kb}$. The strong cross-hybridization of probe EE3.8 with a 3.35-kb murine genomic fragment suggests an evolutionary conservation of sequences in this region.

To investigate whether additional rearrangements of the translocation region take place in NF1, Southern transfers following PFGE of NruI, SacII, and NotI digests of DNA from 38 independent NF1 lymphoblestoid cell lines were examined with EVI2 sequences. With the exception of the two translocations already mentioned, no qualitative changes (i.e., no new fragments) were observed. We would expect to have seen deletions as small as $40 \mathrm{~kb}$ had they been present.

To look for smaller deletions, we tested EcoRI and Bam HI digests of DNA from 87 unrelated NF1 patients for rearrangements or deletions with the pHU39.3 and E-9 probes, and BamHI digests with each of the four cosmids that define the EVI2 contig encompassing the breakpoints. We saw neither qualitative changes in the patterns seen (except for RFLPs with EcoRI and BamHI) nor quantitative reductions in signal intensities relative to control probes. Moreover, examination of the segregation of EcoRI, BamHI, and TaqI RFLPs at the EVI2 locus in 51 NF1 families yielded no evidence for rearranged or deleted alleles at the EVI2 locus.

\section{DISCUSSION}

Through a combination of genetic linkage analysis, somatic cell hybrid mapping, and PFGE analysis of large DNA fragments, a cloned segment of a specific human gene, EVI2, has been found to lie between the breakpoints of two independent translocations in pa- tients with NF1. This cloned human sequence is a bona fide homolog to the murine tumor-associated gene, as the DNA sequence, gene structure, and tissue specificity of its mRNA are closely related (Buchberg et al., submitted for publication; Cawthon et al., 1990).

PFGE analysis of DNA from the balanced $t(17 ; 22)$ LCL with the 17L1A, HU39.3, and E-9 probes failed to reveal derivative PFGE fragments in NotI, SacII, and $B s s$ HII digests. This initially suggested that the $t(17 ; 22)$ breakpoint might be located distally from the HTF " $B$ " island. However, we now know that this is not the case, as these sites are not present in the two cosmids that span the $t(17 ; 22)$ breakpoint, cEVI20 or cT315. This HTF island must be more than $25 \mathrm{~kb}$ distal to the $t(17 ; 22)$ breakpoint, and a corresponding HTF island must be present on chromosome 22 near the translocation breakpoint. This may be by chance, but conceivably it could reflect a regional relationship of homology between these two chromosomes. Such a speculation is of particular interest because the chromosome 22 breakpoint region overlaps with the possible location of the bilateral acoustic neurofibromatosis (BANF or NF2) gene (Rouleau et al., 1990).

The high incidence of new mutations leading to NF1 (1 in 10,000 gametes per generation; Riccardi and Eichner, 1986) might suggest, by analogy with mutations leading to Duchenne muscular dystrophy (Monaco et al., 1986), that frequent deletion or rearrangements may occur at the NF1 locus. However, our failure to detect rearrangements or large deletions in the region of the two NF1 translocation breakpoints suggests that this form of mutation-although it has occurred in the two cases that provided our translocation cell linesis not the predominant class of mutation at this part of the NF1 locus.

Localization of $E V I 2$ between two NF1 translocation breakpoints is consistent with our a priori expectation for the mapping of the NF1 gene. However, two additional transcripts apparently unrelated to $E V I 2$ have been found between the two NF1 translocation breakpoints, and a third transcript lies just telomeric to both NF1 breakpoints (Cawthon et al., 1990).

It seems likely that we are now either within or close to the NF1 gene. This marks the completion of an important stage for NF1 in the general paradigm for gene identification through mapping (Botstein et al., 1980; Monaco et al., 1986; Friend et al., 1986; Royer-Pokora et al., 1986; Riordan et al., 1989): an autosomal gene of unknown biochemistry has been precisely mapped through a combination of physical and genetic technologies, and components of expressed genes in the region have been identified (Cawthon et al., 1990). It now remains to specify the NF1 gene through identification of specific mutations in NF1 patients. 


\section{ACKNOWLEDGMENTS}

We thank G. W. Dewald, J. F. Gusella, A. Menon, V. V. Michaels, M. A. Schmidt, and B. R. Seizinger for the t1;17 cell lines. We also thank M. Skolnick for assistance in collection of NF1 patients, $K$. Ward for the segregation study of EVI-2 polymorphisms in NF1 families, and L. Andersen for helpful suggestions. A.-K. Frej and M. Robertson provided technical assistance, and R. Foltz edited the manuscript and prepared the figures. Research was supported in part by the National Cancer Institute, Department of Health and Human Services, under Contract N01-CO-74101 with BRI. R.W. is an investigator, and F.S.C. an associate investigator, at the Howard Hughes Medical Institute.

Note added in proof. PFGE analysis of 40 additional NF1 patient DNAs reveals 2 samples, each with a smaller fragment in addition to the normal NotI fragment that encompasses the two translocation breakpoints. This provides additional support for the localization of $N F 1$ to this region.

\section{REFERENCES}

1. BARKER, D., SCHAFER, M., AND WHITE, R. (1984). Restriction sites containing $\mathrm{CpG}$ show a higher frequency of polymorphism in human DNA. Cell 36: 131-138.

2. Barker, D., Wright, E., Nguyen, K., Cannon, L., Fain, P., Goldgar, D., BISHOP, D. T., CAREY, J., BATY, B., KivLIN, J., Willard, H., Waye, J. S., Greig, G., LeinWaNd, L., NaKaMURA, Y., O'CONNELL, P., LePPERT, M., LALOUEL, J.-M., WHITE, R., AND SKOLNICK, M. (1987). Gene for von Recklinghausen neurofibromatosis is in the pericentromeric region of chromosome 17. Science 236: 1100-1102.

3a. BENTON, W. D., AND DAVIS, R. W. (1977). Screening lambdagt recombinant clones by hybridization to single plaques in situ. Science 196: 180-182.

3b. BIRD, A. P. (1986). CpG-rich islands and the function of DNA methylation. Nature (London) 321: 209-213.

4. Botstein, D., White, R., SkolNick, M., AND Davis, R. (1980). Construction of a genetic linkage map in man using restriction fragment length polymorphism. Amer. J. Hum. Genet. 32: 314331.

5. BuchBerg, A. M., Bedigian, H. G., TAYLoR, B. A., Brownell, E., IHLE, J. N., NAGATA, S., Jenkins, N. A., AND CopEland, N. (1988). Localization of Evi-2 to chromosome 11: Linkage to other proto-oncogene and growth factor loci using interspecific backcross mice. Oncogene Res. 2: 149-165.

6. Buchberg, A. M., Brownell, E., Nagata, S., Jenkins, N., AND COPELAND, N. (1989). A comprehensive genetic map of murine chromosome 11 reveals extensive linkage conservation between mouse and human. Genetics 122: 153-161.

7. CaWthun, R., O'CONNELl, P., BuchBerg, A. M., ViskochI, D., Weiss, R. B., Culver, M., Stevens, J., Jenkins, N. A., COPELAND, N. G., AND WHITE, R. (1990). Identification and characterization of transcripts from the neurofibromatosis 1 region: The sequence and genomic structure of EVI2 and mapping of other transcripts. Genomics 7, 555-565.

8. CARle, G. F., AND Olson, M. V. (1984). Separation of chromosomal DNA molecules from yeast by ortholgonal field alteration gel electrophoresis. Nucleic Acids Res. 12: 5647-5664.

9. Cavenee, W., Leach, R., Mohandas, T., Pearson, P., and WHITE, R. (1984). Isolation and regional localization of DNA segments revealing polymorphic loci from human chromosome 13. Amer. J. Hum. Genet. 36: 10-24.

10. CHU, G., Vollrath, D., AND DAvis, R. (1986). Separation of large DNA molecules by contour-clamped homogeneous electric fields. Science 234: 1582-1585.

11. Crowe, F. W., Schull, W. T., AND NeEL, J. F. (1956). “A Clinical, Pathological, and Genetic Study of Multiple Neurofibromatosis," Charles C. Thomas, Springfield, IL.

12. DAUSSET, J. (1986). Le centre d'etude du polymorphisme humain. La Presse Medicale 15: 1801-1802.

13. FeINBERG, A., AND VoGELSTEIN, B. (1984). Addendum: A technique for radiolabeling DNA restriction endonuclease fragments to high specific activity. Anal. Biochem. 137: 266-267.

14. Fountain, J. W., Wallace, M. R., Brereton, A. M., O'CoNNELL, P., WHITE, R., RICH, D. C., LEDBETTER, D. H., LEACH, R. J., FournieR, R. E. K., MENON, A. G., GuSELlA, J. F., BARKER, D., STEPHENS, K., AND Collins, F. S. (1989a). Physical mapping of the von Recklinghausen neurofibromatosis region on chromosome 17. Amer. J. Hum. Genet. 44: 58-67.

15. Fountain, J. W., Watuace, M. R., BRuce, M. S., Seizinger, B. R., MenoN, A. G., Gusella, J. F., Michels, V. V., SchMIDT, M. A., Dewald, G. W., AND Collins, F. S. (1989b). Physical mapping of a translocation breakpoint in neurofibromatosis. Science 244: 1085-1087.

16. Friend, S. H., Bernards, R., Rogeld, S., WeinBerg, R. A., RAPAPORT, J. M., ALBERT, D. M., AND DRYJA, T. P. (1986). A human DNA segment with properties of the gene that predisposes to retinoblastoma and osteosarcoma. Nature (London) 323: 643-646.

17. Gardiner, K., LAAS, W., AND PATERSON, D. (1986). Fractionation of large mammalian DNA restriction fragments using vertical pulsed-field gradient electrophoresis. Somatic Cell Mol. Genet. 12: 185-195.

18. Goldgar, D. E., Green, P., Parry, D. M., AND Mulvihill, J. J. (1989). Multipoint linkage analysis in neurofibromatosis type 1: An international collaboration. Amer. J. Hum. Genet. 44: 6-12.

19. GrunsteIN, M., AND HoGNESS, D. (1975). Colony hybridization: A method for the isolating of cloned DNAs that contain a specific gene. Proc. Natl. Acad. Sci. USA 72: 3961-3965.

20. Lathrop, G. M., Lalouel, J.-M., Julier, C., AND OTT, J. (1985). Multilocus linkage analysis in humans: Detection of linkage and estimation of recombination. Amer. J. Hum. Genet. 37: 482-498.

21. LeDBETTER, D. H., KICH, D. C., O'CONNELL, P., LEPPERT, M., AND CAREY, J. C. (1989). Precise localization of NF1 to $17 \mathrm{q} 11.2$ by balanced translocation. Amer. J. Hum. Genet. 44: 20-24.

22. Menon, A. G., Ledbetter, D. H., Rich, D. C., Seizinger, B. R., Rouleau, G. A., Michaels, V. F., SchmidT, M. S., DEWALD, G., DellatorRe, C. M., Haines, J. L., AND GuSElla, J. F. (1989). Characterization of a translocation within the von Recklinghausen neurofibromatosis region of chromosome 17. Genomics 5: 245-249.

23. Monaco, A., Neve, R., Colletti-Feener, C., Bertelson, C., KURNIT, D., AND KUNKEL, L. (1986). Isolation of candidate cDNAs for portions of the Duchenne muscular dystrophy gene. Nature (London) 323: 646-650.

24. O'Connell, P., Leach, R., Ledbetter, D., CAwThon, R., CUlver, M., EldRIDGe, J. R., FreJ, A.-K., HOLM, T., WOLFF, E., Thayer, M., Schafer, A., Fountain, J., Wallace, M., Collins, F., SkOlNick, M., RICH, D., FouRNIER, R. E. K., BATY, B., CAREY, J., LePPERT, M., LATHRop, G. M., LALOUEL, J.-M., AND WHITE, R. (1989a). Fine structure DNA mapping studies of the chromosomal region harboring the genetic defect in neurofibromatosis type 1. Amer. J. Hum. Genet. 44: 51-57.

25. O'Connell, P., Leach, R., CaWthon, R., Culver, M., Ste VENS, J., VISKOCHIL, D., FOURNIER, R. E. K., RICH, D., LED. BETTER, D., AND WHITE, R. (1989b). Two von Recklinghausen 
neurofibromatosis translocations map within a 600 -kb segment of 17q11.2. Science 244: 1087-1088.

26. ReEn, K. C., ANn MANN, D. A. (1985). Rapid transfer of DNA from agarose gels to nylon membranes. Nucleic Acids Res. 13: $7207-7221$.

27. RioRdAN, J. R., Rommens, J. M., KEREM, B.-S., ALON, N., RozMahel, R., GrzelczaK, Z., Zielenski, J., LoK, S., Plavsic, N., Chou, J.-L., Drumm, M., IAnuzzi, M. C., Collins, F. S., AND TSU, L. C. (1989). Identification of the cystic fibrosis gene: Cloning and characterization of the complementary DNA. Science 245: 1066-1073.

28. RICCARDI, V. M., AND EICHER, J. E. (1986). "Neurofibromatosis: Phenotype, Natural History, and Pathogenesis," Johns Hopkins Univ. Press, Baltimore, MD.

29. Rouleau, G. A., Seizinger, B. R., Wertellecki, W., Haines, J. L., Superneau, D. W., Martuza, R. L., Gusella, J. F. (1990). Flanking markers bracket the neurofibromatosis type 2 gene on chromosome 22. Amer. J. Hum. Genet. 46: 323-328.

30. ROYER-POKORA, B., KUNKEL, L., MONACO, A., GOFF, S., NEWBURGER, P., BAEHNER, R., COLE, F., CURNUTTE, J., AND ORKIN, $S$. (1986). Cloning the gene for an inherited human disorderchronic granulomatous disease-on the basis of its chromosomal location. Nature (London) 322: 32-38.

31. SchmidT, M. A., Michels, V. V., AND Dewald, G. W. (1987). Cases of neuro-fibromatosis with rearrangements of chromosome 17 involving band 17q11.2 Amer. J. Med. Genet. 28: 771777 .
32. SCHWARTZ, D. C., AND CANTOR, C. K. (1984). Separation of yeast chromosome-sized DNAs by pulsed-field gel electrophoresis. Cell 37: 67-75.

33. SEed, B., PARKer, R. C., AND Davidson, N. (1982). Representation of DNA sequences in recombinant DNA libraries prepared by restriction enzyme partial digestion. Gene 19: 201299.

34. Seizinger, B., Rouleau, G., Ozelrus, L., LANe, A., Faryniarz, A., Chao, M., Huson, S., Korf, B., Parry, D., Pericak-Vance, M., Collins, F., Hobbs, W., Falcone, B., Iannazzi, J., RoY, J., ST. GEORGE-HYSLOP, P., TANZI, R., BotHWELl, M., UPADHYAYA, M., HaRPER, P., GoldSTeIN, A., HOOVER, D., BADER, J., Spence, M., Mulvihill, J., AYlsworth, A., VANCE, J., Rossenwasser, G., Gaskell, P., Roses, A., MartuzA, R., BREAKFIELD, X., AND GUSELLA, J. (1987). Genetic linkage of von Recklinghausen neurofibromatosis to the nerve growth factor receptor gene. Cell 49: 589-594.

35. StumpF, D. A., Alksne, J. F., ANNEgers, J. F., Brown, S. S., Conneally, P. M., Housman, D., LePPERT, M., MilleR, J. P., Moss, M. L., Plleggi, A. J., Rapin, I., Strohman, R. C., SWANSON, L. W., AND ZimmERman, A. (1988). Neurofibromatosis. Arch. Neurol. 45: 575-578.

36. WHITE, R., LEPPERT, M., BISHOP, D. T., BARKER, D., BERKOWITZ, J., BROWN, C., CALl LHAN, P., HOLM, T., AND JEROMINSKI, L. (1985). Construction of linkage maps with DNA markers for human chromosomes. Nature (London) 313: 101-105. 